\title{
EKSISTENSI DAN PERAN ADVOKAT DALAM MEMBERI BANTUAN HUKUM DI PENGADILAN AGAMA
}

\author{
Edi Gunawan ${ }^{1}$
}

\begin{abstract}
Abstrak
Advokat dalam memberikan bantuan hukum kepada masyarakat yang membutuhkannya tidak membedakan agama, ras, budaya, keturunan, pangkat dan jabatan, bahkan kaya atau miskin. Hal itu guna untuk mencapai kebenaran dan keadilan di depan hukum. Advokat dalam memberikan jasa hukum dapat berperan sebagai pendamping, pemberi advise hukum, atau menjadi kuasa hukum atas nama kliennya. Advokat termasuk profesi yang mulia karena ia dapat menjadi mediator bagi para pihak yang bersengketa tentang suatu perkara, baik yang berkaitan dengan perkara pidana, perdata, maupun tata usaha negara. Advokat juga dapat menjadi fasilitator dalam mencari kebenaran dan menegakkan keadilan untuk membela hak asasi manusia dan memberikan pembelaan hukum yang bersifat bebas dan mandiri. Eksistensi dan peran seorang advokat untuk beracara dan menggunakan jasanya di Pengadilan Agama sama dengan eksistensi dan perannya di pengadilan umum. Walaupun perkara yang ditangani berbeda dan masyarakat yang menggunakan jasa advokat di Pengadilan Agama lebih sedikit. Tantangan seorang advokat untuk beracara dan menggunakan jasanya di Pengadilan Agama adalah tidak semua hukum acara yang berlaku di Pengadilan Agama diberlakukan juga di pengadilan umum, sehingga sebagian advokat yang menggunakan jasanya di Pengadilan Agama tidak menguasai sepenuhnya hukum acara yang berlaku di Pengadilan Agama.
\end{abstract}

Kata Kunci: Eksistensi, Peran, Advokat, Bantuan Hukum, Pengadilan Agama

\section{Pendahuluan}

Peradilan Agama merupakan salah satu instansi yang sangat urgen dalam tata kehidupan masyarakat. Khususnya bagi umat Islam. Secara filisofi ia dibentuk dan dikembangkan untuk memenuhi tuntutan penegakan hukum dan keadilan berdasarkan aturan Allah swt dalam pergaulan di tengah kehidupan masyarakat, yang merupakan perwujudan tauhid Ilahi guna menata kehidupan masyarakat Indonesia.

Peradilan Agama merupakan suatu badan yang memiliki tugas pokok menerima, memeriksa, mengadili dan menyelesaikan perkara-perkara yang

\footnotetext{
${ }^{1}$ Penulis adalah dosen tetap pada STAIN Manado
} 
diajukan kepadanya. Untuk menyelesaikan suatu perkara di depan pengadilan dalam rangka menegakkan hukum dan keadilan di Indonesia senantiasa mengikuti prosedur dan aturan yang berlaku di pengadilan tersebut. Kehadiran UU No. 7 Tahun 1989 tentang Peradilan Agama yang telah lama dinanti-nanti itu tampaknya cukup melegakan hati. Harapan akan semakin kukuh dan jelasnya eksistensi dan kompetensi Peradilan Agama terasa segera terwujud. Sehingga Peradilan Agama tidak lagi dipandang sebagai pengadilan kelas dua atau pengadilan pinggiran yang keberadaannya ibarat sebuah benda, tidak dicinta tetapi juga tidak dibenci. Kehadirannya tidak mencukupkan, kepergiannya juga tidak mengurangkan. Begitulah pada masa-masa yang lalu, lembaga Peradilan Agama dibiarkan dalam keadaan hidup segan matipun tak mau ${ }^{2}$.

Eksistensi Peradilan Agama di Indonesia adalah dalam rangka mengupayakan terwujudnya suasana perikehidupan yang aman dan kerukunan antar warga Indonesia yang beragama Islam sehingga mengharuskan Peradilan Agama tetap konsisten terhadap prinsip-prinsip keadilan, kebenaran, ketertiban dan kepastian hukum dengan tetap memperhatikan secara sungguh-sungguh setiap perubahan sosial dan pergeseran nilai yang terjadi ditengah kehidupan masyarakat sebagai akibat kemajuan ilmu pengetahuan dan teknologi.

Pada Undang-undang N0. 4 tahun 2004 tentang kekuasaan kehakiman pasal 37, menyatakan bahwa setiap orang yang tersangkut perkara berhak memperoleh bantuan hukum. Dalam memberikan bantuan hukum tersebut advokat atau penasehat hukum membantu memperlancar penyelesaian perkara dengan menjunjung tinggi pancasila, hukum dan keadilan ${ }^{3}$.

Problem penegakan hukum di Indonesia memang sudah sangat memprihatinkan, keprihatinan terhadap kondisi hukum tidak saja karena materi hukumnya yang tidak lagi mampu menjawab tingkat perkembangan kebutuhan masyarakat terhadap hukum, tetapi juga karena seluruh sistem yang terkait dengan

\footnotetext{
${ }^{2}$ Hadi Daeng Mapuna, Problematika Pelaksanaan Hukum Acara Peradilan Agama (Cet. I; Makassar: CV. Kencana, 2003), h. 5

${ }^{3}$ H.A Mukti Arto, Praktek Perkara Perdata pada Pengadilan Agama (Cet. I; Yogyakarta: Pustaka Pelajar, 1996), h. 50
} 
upaya penegakan hukum tidak lagi mampu memberikan pelayanan terbaiknya kepada masyarakat untuk memperoleh keadilan di depan hukum.

Advokat merupakan profesi yang terhormat karena adanya profesionalisme di dalamnya. Di samping itu, profesi advokat bukan semata-mata mencari nafkah, namun di dalamnya terdapat idealisme dan moralitas yang sangat dijunjung tinggi ${ }^{4}$. Advokat adalah profesi yang bebas, mandiri, dan bertanggung jawab dalam menegakkan hukum,sehingga perlu dijamin dan dilindungi oleh negara melalui undang-undang demi terselenggaranya penegakan supremasi hukum 5 .

Orang yang mengetahui tentang seluk beluk hukum diharapkan dapat membantu mereka yang tidak mengerti hukum, karena orang yang belum pernah berhubungan dengan pengadilan dan harus berperkara, biasanya mereka akan gugup menghadapi hukum, maka seorang pembantu atau wakil sangat bermanfaat $^{6}$. Bantuan hukum yang diberikan oleh seorang advokat bukan hanya bermanfaat bagi orang yang berperkara saja, tetapi juga memberikan bantuan yang sangat besar bagi hakim dalam memeriksa suatau perkara, karena mampu memberikan sumbangan pikiran dalam menyelesaikan suatu perkara-perkara yang berkenaan dengan hukum yang timbul baik dalam lingkungan pengadilan maupun dimasyarakat umum.

Dalam mengajukan gugatan, harus diperhatikan dengan benar bahwa yang diberi kuasa menuntut hukum harus benar-benar orang yang dapat mewakili yang bersangkutan dalam perkara tersebut dan telah memenuhi syarat-syarat untuk mewakili para pihak-pihak yang berperkara dengan sah berdasarkan hukum ${ }^{7}$.

Saat ini lembaga advokat atau advokat telah banyak beroperasi di pengadilan, baik pada Pengadilan Negeri, Pengadilan Militer, maupun pada Pengadilan Tata Usaha Negara. Sedangkan di lingkungan Pengadilan Agama

\footnotetext{
${ }^{4}$ Ropaun Rambe, Teknik Praktek Advokat (Cet. I; Jakarta: PT. Grasindo Anggota IKAPI, 2001), h. 27

${ }^{5}$ Sebagai salah satu bentuk profesi yang sangat dijunjung tinggi oleh negara, maka dibuat satu undang-undang yang mengaturnya, yakni UU No. 18 tahun 2003 tentang advokat. 2002), h. 18

${ }^{6}$ Sudikno Mertokusumo, Hukum Acara Perdata Indonesia (Cet. I; Yogyakarta: Liberty,

${ }^{7}$ Retno Sutianto dkk, Hukum Acara Perdata dalam Teori dan Praktek (Cet. II; Bandung: Mandar Maju, 1999), h. 14
} 
belum terlalu banyak menggunakan jasanya. Padahal sebenarnya banyak perkara di Pengadilan Agama yang sangat membutuhkan bantuan hukum dari seorang advokat.

\section{Pembahasan}

\section{A. Pengertian Advokat}

Pada dasarnya, advokat berasal dari bahasa latin, yakni "advokatus" yang bermakna seorang ahli hukum yang memberikan bantuan atau pertolongan dalam soal-soal hukum, bantuan atau pertolongan ini bersifat memberi nasehat sebagai jasa-jasa yang baik, dalam perkembangannya kemudian dapat diminta oleh siapapun yang memerlukan atau membutuhkan untuk beracara dalam hukum ${ }^{8}$.

Advokat adalah seorang yurist, seorang ahli hukum dari seorang sarjana hukum. Jadi, walaupun seorang ahli tentang hukum tetapi bukan sarjana hukum, maka ia tidak dapat dikatakan sebagai advokat, melainkan hanya dapat dikatakan sebagai pengacara, itu dikarenakan bahwa pengacara bisa bukan dari seorang sarjana hukum, akan tetapi ia seorang ahli hukum. Seorang advokat selain memberikan nasehat hukum kepada kliennya, ia juga bertanggung jawab secara langsung terhadap pembelaan perkara itu, dan mewakili kliennya dalam beracara dan memyelesaikan perkara-perkara yang diajukan klien kepada pengadilan. Advokat adalah orang yang mewakili kliennya untuk melakukan tindakan hukum berdasarkan surat kuasa yang diberikan untuk pembelaan, penuntutan pada acara persidangan di pengadilan ${ }^{9}$.

Sebelum berlakunya Undang-undang No.18 Tahun 2003 tentang advokat, istilah advokat, pengacara, penasehat hukum dan konsultan hukum dalam praktek hukum di Indonesia mempunyai perbedaan pengertian yang cukup bermakna, walaupun dalam bahasa Inggris semua istilah tersebut secara umum disebut sebagai lawyer atau ahli hukum ${ }^{10}$.

\footnotetext{
${ }^{8}$ Lasdia Wlas, Cakrawala Advokat Indonesia (Cet. I; Yogyakarta: Liberty, 1989), h. 4

${ }^{9}$ Rahmat Rosyadi \& Sri Hartini, Advokat dalam Perspektif Islam dan Hukum Positif (Cet. I; Jakarta: Ghalia Indonesia Anggota IKAPI, 2003), h. 72

${ }^{10}$ Namun perbedaan pengertian di atas akan jelas apabila kita merujuk pada definisi tentang advokat pada bab I pasal 3 (1) Anggaran Dasar AAI bahwa" Advokat adalah termasuk penasehat hukum dan para konsultan hukum", namun pada ayat berikutnya yaitu ayat 2 paragraf pertama berbunyi “ Konsultan hukum adalah profesi yang dijalankan oleh para sarjana hukum
} 


\section{B. Syarat-syarat Advokat Menurut Undang-undang}

Jauh sebelum berlakunya Undang-undang N0.18 Tahun 2003 tentang Advokat, sudah ada beberapa peraturan perundang-undangan yang secara eksplisit mengisyaratkan bahwa profesi advokat, penasehat hukum, pengacara, dan konsultan hukum atau istilah alin kuasa hukum, telah diatur secara khusus dan tegas dalam peraturan-peraturan yang setingkat dengan Undang-undang. Dalam UU No. 8 Tahun 1981 tentang Hukum Acara Pidana, menyatakan bahwa "seorang penasehat hukum adalah seorang yang memenuhi syarat yang ditentukan oleh atau berdasarkan Undang-undang untuk memberikan bantuna hukum"11.

Pada dasarnya semua advokat yang resmi terdaftar sebagai anggota Persatuan Advokat Indonesia (PERADI) dapat beracara di Mahkamah Konstitusi. Akan tetapi, untuk dapat diterima beracara di Mahkamah Konstitusi diatur bahwa para advokat itu harus terlebih dulu terdaftar di Kepaniteraan Mahkamah Konstitusi. Mahkamah konstitusi tentunya berwenang mengatur sendiri mengenai hal-hal semacam itu dengan Peraturan Mahkamah Konstitusi (PMK) ${ }^{12}$.

Dengan adanya peraturan yang mendasar dari kedudukan advokat dan profesi advokat, dapatlah diharapkan kejelasan mengenai organisasi advokat sebagai Publiekrechtelijk Licham (Badan Hukum), susuanan, struktur organisasi dan kompetensi dari asosiasi advokat, siapa yang bisa menjadi anggota pimpinan advokat, pembentukan dan penunjukan anggota dewan kehormatan, anggota dewan pengawas, personalia, pembukuan, laporan tahunan, rapat, hak suara, disiplin advokat, pengaduan, persyaratan untuk menjadi advokat, ujian yang diadakan oleh asosiasi advokat, kewenangan dan kewajiban advokat, praktek advokat, pengangkatan dan pengambilan sumpah advokat, kantor advokat, peradilan disiplin, teguran, skorsing, pemecatan, sidang tentang pengaduan, magang, tentang procureur, spesialisasi, pajak, kerjasama, pensiun, yayasan

lulusan Universitas Negeri atau yang dipersamakan, bukan Pegawai Negeri/ Angkatan Bersenjata Republik Indonesia (ABRI) berdasarkan surat izin usaha yang khusus diberikan untuk itu oleh orang yang berwenang dan tidak menjalankan praktek profesinya di muka pengadilan. Lihat Ropaun Rambe, Teknik Praktek Advokat, h. 6

${ }^{11}$ Republik Indonesia, Kitab Undang-undang Hukum Pidana dan Kitab Undang-undang Hukum Acara Pidana (Cet. III; Jakarta: Gema Press, 2003), h. 40

${ }^{12}$ Jimly Assiddiqie, Hukum Acara Pengujian Undang-undang (Cet. I; Jakarta: Setjen dan Kepaniteraan MKRI, 2005), h. 198 
pensiun untuk advokat yang cacat, honor, kerekanan, aturan berpraktek, peraturan tentang advokat asing, hubungan antar advokat dengan klien, hubungan advokat dengan sesama rekannya, hubungan advokat dengan badan pengadilan, hubungan dengan panitera, hubungan dengan hakim, pendidikan dan pelatihan advokat, keharusan belajar seumur hidup, lulus ujian kode etik dan segala sesuatu yang berhubungan dengan jasa hukum yang diberikan advokat dan profesi advokat ${ }^{13}$.

Undang-undang No.18 Tahun 2003 tentang advokat secara jelas mengemukakan syarat-syarat untuk dapat diangkat sebagai advokat. Hal itu dijelaskan dalam pasal 2 ayat (1) yang memberikan persyaratan umum bahwa “yang dapat diangkat sebagai advokat adalah sarjana yang berlatar belakang pendidikan tinggi hukum dan setelah mengikuti pendidikan khusus advokat yang dilaksanakan organisasi”. Selanjutnya persyaratan umum yang diuraikan pasal 2 ayat (1) tersebut dijabarkan secara lebih rinci dalam pasal 3 ayat (1) yang menyatakan bahwa "untuk dapat diangkat menjadi advokat harus memenuhi persyaratan sebagai berikut:

a. Warga negara Republik Indonesia;

b. Bertempat tinggal di Indonesia;

c. Tidak berstatus sebagai Pegawai Negeri atau pejabat negara;

d. Berusia sekurang-kurangnya 25 (dua puluh lima) tahun;

e. Berijasah sarjana yang berlatar belakang pendidikan tinggi hukum sebagaimana dimaksud dalam pasal 2 ayat (1);

f. Lulus ujian yang diadakan oleh organisasi advokat;

g. Magang sekurang-kurangnya 2(dua) tahun terus menerus pada kantor advokat;

h. Tidak pernah dipidana karena melakukan tindak pidana kejahatan yang diancam dengan pidana penjara 5 (lima) tahun atau lebih;

i. Berperilaku baik, jujur, bertanggung jawab, adil, dan mempunyai integritas yang tinggi ${ }^{14}$.

\footnotetext{
${ }^{13}$ Ropaun Rambe, op.cit, h. 16-17

${ }^{14}$ Republik Indonesia, Undang-undang No. 24 Tahun 2003 tentang Mahkamah Konstitusi disertai dengan Undang-undang No.18 Tahun 2003 tentang Advokat (Cet. I; Surabaya: CV. Karina Anfaka Perdana, 2003), h. 56
} 
Melihat persyaratan untuk menjadi advokat yang diuraikan pasal 3 (1) di atas, dibandingkan dengan persyaratan advokat yang berlaku sebelum Undangundang advokat, yaitu tentang surat edaran Mahkamah Agung Nomor 047/TUN/III/1989 tanggal 18 maret 1989 tentang penerimaan calon praktek advokat, agaknya Undang-undang terasa lebih membatasi dan selektif. Meskipun dari segi persyaratan pendidikan minimal berijasah sarjana yang berlatar belakang pendidikan tinggi hukum yang diartikan luas sebagai lulusan fakultas hukum, fakultas syariah, Perguruan Tinggi Hukum Militer dan Perguruan Tinggi Ilmu Kepolisian.

Pengangkatan seorang advokat yang diatur melalui surat edaran Mahkamah Agung Nomor 047/TUN/III/1989 secara lengkap mengatur tentang berbagai ketentuan, mulai dari proses penerimaan, panitia pelaksana, penentuan syarat-syarat permohonan calon, materi ujian, sampai kepada peranan dan keterlibatan organisasi profesi advokat ${ }^{15}$.

Pengangkatan advokat yang cenderung membatasi dan selektif tersebut ditinjau dari adanya persyaratan mengikuti pendidikan khusus profesi advokat dan magang sekurang-kurangnya 2 (dua) tahun secara terus menerus pada kantor advokat. Padahal sebelumnya, kedua persyaratan tersebut tidak mutlak dimiliki seorang calon advokat.

Untuk menjadi seorang advokat tidak bisa sembarang orang. Ia memerlukan persyaratan khusus yang disesuaikan dengan kebutuhan dan perkembangan problematika hukum. Seorang yang akan menjadi advokat harus mempersiapkan diri dengan segala kemampuan terutama yang berkaitan dengan pengetahuan hukum, baik hukum formil maupun hukum materil. Seorang advokat tidak hanya ditampilkan secara fisik, tetapi terpenting adalah sifat, sikap kepribadian dan akhlakul karimah. Seorang advokat harus selalu fleksibel, kreatif, dan mempunyai kualifikasi serta karakter yang substantif. Antara lain ia harus mempunyai dosis semangat yang cukup, karena tanpa itu maka sulit seorang advokat dapat bekerja secara maksimal. Seorang advokat selain harus mempunyai

${ }^{15}$ Yudha Pandu, Klien dan Advokat dalam Praktek (Cet. III; Jakarta: PT. Abadi, 2004), h. 
kualifikasi kepribadian yang baik, juga harus memiliki independensi karena hal itu sangat penting agar mereka dapat menjalankan tugas secara baik dalam membela kliennya tanpa ada intervensi dari pihak manapun. Karena independensi ini yang akan menjamin tegaknya hukum bagi pencari keadilan.

Sebagai seorang advokat, pengacara, atau penasehat hukum harus memenuhi syarat khusus sebagai berikut:

1. Keahlian dalam hukum.

Seorang yang berprofesi sebagai pengacara, advokat, dan penasehat hukum senantiasa bergelut dengan ilmu hukum dan pengetahuan masyarakat yang berkembang, maka diperlukan seorang ahli hukum yang sarjana hukum yang berkemampuan melakukan tugas kewajiban yurist, baik berupa teori maupun praktek yang diterapkan sesuai dengan perkembangan sosial dalam lingkungannya secara obyektif dan rasional guna menemukan keadilan hukum dan kebenaran hukum $^{16}$.

\section{Kebebasan profesi}

Yang dimaksud kebebasan profesi adalah tidak terikat pada suatu organisasi atasan atau organisasi induk, tidak mempunyai hubungan jenjang kedinasan atau hierchis atasan yang bekerja dengan bebas, tidak terikat oleh siapapun dalam menjalankan suatu perkara, namun dengan demikian tidak berarti meninggalkan rasa solidaritas terhadap rekan se profesi maupun instansi yang terkait. Kebebasan profesinya merupakan kebebasan oleh rasa tanggung jawab atas dasar landasan hukum pancasila dan UUD $1945^{17}$.

3. Pengabdian kepada kepentingan umum

Bersedia membantu dan menolong orang-orang yang berada dalam kesulitan karena mempunyai suatu permasalahan memberikan bantuan jasa-jasa hukum kepada siapapun juga yang memerlukannya, guna terhindar dari permasalahan yang dihadapi oleh pencari keadilan. Tentu dengan batas-batas

\footnotetext{
${ }^{16}$ Lasdin Wlass, op.cit, h. 6

${ }^{17}$ Ibid.
} 
keyakinan dengan bahwa yang akan dibela tidak menjadi korban ketidakadilan. Kepentingan umum lebih diutamakan daripada kepentingan pribadinya ${ }^{18}$.

4. Profesinya tidak untuk mencari kekayaan

Seorang advokat adalah bukan pegawai negeri, bukan pegawai swasta suatu instansi. Akan tetapi merupakan pekerjaan swasta. Jadi honorarium bebas jasa yang diperolehnya berasal dari kliennya dan insidentil serta tidak boleh menerima honorarimu lain dalam perkara lain yang bertentangan dengan perkara yang sedang dibela dan tidak boleh menarik honorarium dan keuntungan yang berlipat ganda ${ }^{19}$.

5. Hubungan kepercayaan dengan klien

Kredibilitas merupakan pertaruhan dalam profesinya, sampai sejauhmana ia dapat menyimpan rahasia kliennya yang dipercayakan kepadanya. Dalam memberikan bantuan kepada kliennya, maka sebelum bertindak harus mendapatkan data-data selengkapnya yang menyangkut permasalahan, bagaimana hubungan kausalitas fakta, delicti dengan fakta yurist yang menyangkut permasalahan kasus yang ada. Dalam memberikan bantuan hukum kepada klien wajib berusaha sekuat tenaga dan pikiran dengan sungguh, baik dalam usaha perdamaian maupun dalam berperkara kasus perdata dan pidana, di dalam dan di luar sidang pengadilan. Dengan demikian akan menimbulkan kepercayaan penuh oleh klien ${ }^{20}$.

6. Merahasiakan kepribadian klien yang dibela

Dengan adanya saling kepercayaan yang dibela dengan pengacara yang membela, karena segala rahasia pribadi klien merupakan rahasia jabatan yang wajib dipegang teguh dalam menjalankan profesinya. Kepadanya diwajibkan menyimpan rahasia-rahasia tertentu yang menyangkut klien dan segala yang menyangkut dengan permasalahan dan wajib mendapatkan perlindungan utama dari pengacara yang memberikan bantuan hukum ${ }^{21}$. Advokat tidak boleh sekali-

${ }^{18}$ Ibid. Lihat pula Kode Etik Advokat Indonesia pasal 2 sub. 2.1 serta pasal 35 UU No. 14 tahun 1970 tentang Kekuasaan Kehakiman.

${ }^{19}$ Ibid, h. 7

${ }^{20}$ Ibid, h. 8

${ }^{21}$ Ibid. 
kali memberikan informasi klien guna kepentingannya sendiri atau kepada lawan perkara agar mendapatkan imbalan dari lawan perkara. Oleh karena itu, seorang advokat dilarang mempunyai kepentingan dalam perkara itu. Perlindungan rahaisa klien ini merupakan kewajiban moral serta rahasia jabatan dan wajib dipengang teguh menurut hukum oleh seorang advokat. Bagi klien yang merasa dirugikan atau merasa rahasia pribadinya tidak terlindungi, maka mereka mempunyai hak untuk menuntut advokat yang membelanya.

7. Hak imunitas profesi

Hak imunitas yaitu hak kekebalan dalam artian suatu hak yang tidak tunduk kepada hukum yang berlaku, hak yang tidak dapat diganggu gugat oleh siapa pun. Seorang pengacara, advokat, dan penasehat hukum yang bertindak untuk kepentingan umum dan dalam melakukan pembelaan kebenaran, maka dirinya perlu mendapatkan perlindungan hukum ${ }^{22}$.

8. Kode etik

Pengertian kode etik kita batasi dalam artian tulisan atau tanda-tanda etis yang mempunyai tujuan tertentu. Mengandung norma-norma hidup yang etis, aturan tata susila, sikap, akhlak budi luhur yang pelaksanaannya diserahkan atas keinsyafan dan kesadaran dirinya sendiri. Oleh karena itu, demi menjunjung kebenaran, harkat, serta keadilan dan hati nurani advokat, perlu menjaga citra dan wibawa, harkat serta martabat dalam menjalankan praktek profesinya. Untuk itu pula perlu suatu ketentuan yang mengatur aturan main bagaimana advokat menjalankan profesinya yaitu kode etik.

Agar supaya terpenuhi persyaratan kualifikasi dan independensi bagi advokat, maka proses pengangkatannya harus selektif melalui tes pengetahuan hukum dan tes kepribadian yang diatur oleh Undang-undang. Keterlibatan organisasi advokat dalam hal pengangkatan advokat adalah menyelenggarakan kode etik. Seorang calon advokat harus terlebih dahulu mengikuti ujian kode etik yang diselenggarakan oleh organisasi advokat, dimana selanjutnya ia nanti akan

\footnotetext{
${ }^{22}$ Perlindungan hukum ini bukan berarti dalam tugas membela perkara bertindak semenamena saja. Hak imunitas ini didasari oleh Kitab Undang-undang Hukum Pidana pasal 310 ayat (3) yang mengatakan " tidak merupakan pencemaran atau pencemaran tertulis, jika perbuatan jelas dilakukan demi kepentingan umum atau karena terpaksa untuk membela diri.
} 
mencatatkan diri sebagai anggotanya. Walaupun pendaftaran untuk mengikuti ujian kode etik dilakukan pada masing-masing organisasi advokat, namun pelaksanaan ujian secara serentak dilakukan secara bersama-sama antar organisasi advokat yang ada.

Dengan adanya persyaratan ujian kode etik yang diselenggarakan oleh organisasi advokat tersebut sepertinya memberikan adanya pengakuan atas keberadaan organisasi untuk menentukan syarat terhadap calon advokat. Karena tidak semua lulusan fakultas hukum dapat diangkat menjadi advokat karena harus melalui seleksi yang ketat agar dapat menghasilkan advokat yang bermutu, sehingga mampu memberikan pelayanan bagi masyarakat pencari keadilan baik itu di muka pengadilan maupun di luar pengadilan.

\section{Tugas-tugas Advokat Menurut Undang-undang}

Tugas adalah merupakan suatu kewajiban. Sesuatu yang merupakan tugas advokat wajib untuk dilakukannya dalam hal pemberian bantuan jasa hukum kepada masyarakat pencari keadilan (klien) yang sedang tersangkut perkara. Oleh karena itu, seorang advokat sebagai salah satu penegak hukum tidak hanya bertanggung jawab kepada kliennya tetapi juga atas masyarakat, bangsa, dan pengadilan.

Tugas advokat pada dasarnya bukanlah sebagai pekerjaan, akan tetapi lebih merupakan sebagai profesi. Karena profesi tidak hanya untuk mengumpulkan materi yang bersifat ekonomin dalam hal mencari nafkah, tetapi lebih utama karena profesi itu lebih bernilai sosial yang tinggi dalam masyarakat. Oleh karena itu, profesi advokat disebut sebagai profesi yang mulia karena profesi ini mewajibkan pembelaan hukum kepada setiap manusia tanpa ada perbedaan. Profesi advokat lahir dari masyarakat yang merindukan kebenaran dan keadilan serta penegakan hukum secara merata di Indonesia.

Tugas advokat adalah membela kepentingan masyarakat dan kliennya. Advokat dibutuhkan pada saat seseorang atau lebih anggota masyarakat menghadapi suatu masalah atau problem dibidang hukum. Dalam menjalankan tugasnya, seorang advokat harus memahami kode etik karena kode etik itu 
merupakan landasan moral seorang advokat dalam menjalankan tugas agar tidak melakukan penyelewengan.

Pada dasarnya tugas pokok seorang advokat dapat dirinci sebagai berikut:

1. Memperjuangkan tegaknya kebenaran keadilan hukum dan hak-hak asasi manusia.

2. Menghayati bahwa profesi advokat adalah mempunyai martabat yang tinggi, mulia dan dihormati.

3. Menaati kode etik advokat.

4. Membela dan melindungi klien pencari keadilan.

5. Meningkatkan pengetahuannya terutama dalam bidang ilmu hukum, perundang-undangan, peraturan-peraturan pemerintah serta perkembangan ilmu sosial lainnya yang berkaitan dengan ilmu hukum.

6. Meningkatkan pembinaan budi pekerti dan budaya sebagai tuntunan pembinaan manusia Indonesia seutuhnya.

7. Melaksanakan tugas pekerjaan profesi dengan segala kejujuran, kesungguhan, kebijaksanaan, keberanian, agar kepentingan yang dipercayakannya dapat terwujud dengan baik dan penuh rasa tanggung jawab.

8. Memberikan bantuan hukum kepada masyarakat pencari keadilan tanpa memandang agama, kepercayaan, aliran politik, keturunan, kewarganegaraan, kedudukan sosial baik kaya maupun miskin.

9. Memberikan bantuan hukum secara cuma-Cuma.

10. Menghormati kepada pengadilan selaku officer of the court dan membantu hakim dalam mencari kebenaran guna mencapai keputusan yang adil.

11. Pertentangan perdebatan di muka sidang pengadilan dalam membela perkara, tidak menjadikan permusuhan pribadi.

Dalam menjalankan tugasnya, seorang advokat harus berfungsi:

a. Sebagai pengawal konstitusi dan hak asasi manusia.

b. Memperjuangkan hak-hak asasi manusia dalam negara hukum Indonesia.

c. Melaksanakan kode etik advokat. 
d. Memegang teguh sumpah advokat dalam rangka menegakkan hukum, keadilan dan kebenaran.

e. Menjungjung tinggi serta mengutamakan idealisme (nilai keadilan dan kebenaran) dan moralitas.

f. Menjungjung tinggi citra profesi advokat sebagai profesi terhormat (officium nobile)

g. Melindungi dan memelihara kemandirian, kebebasan, derajat, dan martabat advokat.

h. Menjaga dan meningkatkan mutu pelayanan advokat terhadap masyarakat.

i. Menangani perkara-perkara sesuai kode etik advokat.

j. Membela klien dengan cara yang jujur dan bertanggung jawab.

k. Mencegah penyalahgunaan keahlian dan pengetahuan yang merugikan masyarakat.

1. Memelihara kepribadian advokat.

m. Menjaga hubungan baik dengan klien maupun dengan teman antara sesama advokat yang didasarkan pada kejujuran, kerahasiaan dan keterbukaan serta saling menghargai dan mempercayai.

n. Memelihara persatuan dan kesatuan advokat agar sesuai dengan wadah tunggal organisasi advokat.

o. Memberikan pelayanan hukum (legal service)

p. Memberikan nasehat hukum (legal advice)

q. Memberikan konsultasi hukum (legal consultation)

r. Memberikan pendapat hukum (legal opinion)

s. Menyusun kontrak-kontrak (legal drafting)

t. Memberikan informasi hukum (legal information)

u. Membela kepentingan klien (litigation)

v. Mewakili klien di muka pengadilan (legal representation)

w. Memberikan bantuan hukum dengan cuma-cuma kepada rakyat yang lemah dan tidak mampu (legal aid $)^{23}$.

\footnotetext{
${ }^{23}$ Ropaun Rambe, op.cit, h. 28-29
} 
Seorang advokat Indonesia harus mampu memiliki kesadaran untuk memberikan nasehat dan bantuan hukum kepada setiap orang yang memerlukannya secara nondiskriminatif tanpa melihat perbedaan agama, kepercayaan, suku, keturunan, keyakinan politik, atau kedudukan sosialnya. Ia merupakan etika normatif yang menjadi kewajiban bagi advokat Indonesia, bahwa ia harus bersedia memberi nasehat dan bantuan hukum yang diminta kepadanya.

\section{Peran Advokat dalam Memberi Bantuan Hukum di Pengadilan Agama}

Semua negara yang ada di dunia ini memiliki lembaga peradilan. Hal ini itu disebabkan karena setiap negara menginginkan penegakan hukum dan hak asasi manusia tak terkecuali negara Indonesia. Entah bagaimana keadaan suatu masyarakat yang ada dalam suatu negara yang tidak memiliki suatu lembaga peradilan. Ksrena lembaga tersebut merupakan kebutuhan pokok masyarakat dan negara itu sendiri. Sehingga mewajibkan pemerintahnya untuk menghadirkan lembaga tersebut.

Keberadaan Pengadilan Agama sebagai pengadilan tingkat pertama yang menangani perkara perdata untuk masyarakat pencari keadilan yang beragama Islam di Indonesia. Pengadilan Agama sebagai lembaga hukum yang berlandaskan pada Alquran dan Pancasila harus mampu memberikan pelayanan yang maksimal terhadap mereka yang menginginkan penegakan hukum, kebenaran dan keadilan. Oleh karena itu, kaitan antara hukum atau peraturan mereka tidak terlepas dari pelaku hukum itu sendiri dalam menentukan suatu putusan yang dihasilkan sebagai produk hukum Pengadilan Agama yang sangat tergantung pada pelaku hukum dan peraturan hukum yang mengikatnya.

Peran advokat dalam memberikan jasa hukum bagi kepentingan klien dengan tujuan untuk melakukan perdamaian bagi para pihak yang bersengketa sangat menentukan. Yang dimaksud peran advokat di sini adalah bagaimana ia dapat menjalankan profesinya sesuai dengan tugas dan fungsinya serta sesuai dengan kode etik dan sumpah advokat. Sedangkan yang dimaksud dengan pemberian jasa hukum yang dilakukan advokat adalah mendampingi, menjadi 
kuasa hukum, memberikan pelayanan hukum kepada klien baik bersifat sosial maupun atas dasar mendapatkan honorarium.

Kedudukan advokat dalam pemeriksaan persidangan dapat bertindak sebagai wakil atau pendamping. Kedudukan ini tergantung kuasa khusus yang diberikan oleh pemberi kuasa. Jika kedudukan yang dikuasakan hanya sebagai pendamping, berarti advokat yang bersangkutan tidak mempunyai hak bicara dalam persidangan. Sebaliknya, jika advokat telah diberi kuasa sebagai wakil, maka sipemberi kuasa tidak lagi mempunyai hak untuk berbicara di dalam persidangan. Pembedaan ini penting agar jalannya persidangan tidak terganggu. Misalnya, karena adanya perbedaan keterangan yang diberikan oleh kuasa dengan keterangan pemohon. Keadaan semacam ini sering terjadi apabila keduanya samasama berbicara dalam persidangan tanpa koordinasi terlebih dahulu di antara mereka sendiri ${ }^{24}$.

Namun demikian, tentu timbul juga kesulitan jika kuasa hukum yang telah ditunjuk sebagai wakil memang tidak menguasai keseluruhan substansi persoalan yang dimohonkan oleh pemohon. Untuk mengatasi hal ini, atas izin majelis hakim, baik kuasa pendamping atau pemberi kuasa yang telah diwakili oleh kuasa dapat saja tetap diberikan kesempatan untuk berbicara jika memang diperlukan. Dalam hal demikian, yang bersangkutan dapat mengajukan permohonan kepada ketua majelis yang akan mempertimbangkan apakah kepadanya perlu diberikan kesempatan berbicara atau tidak.

Ada tiga hal yang menyebabkan masyarakat memilih untuk menggunakan jasa advokat dalam mewakili perkaranya untuk diselesaikan di Pengadilan Agama, antara lain;

1. Pada umumnya pengetahuan masyarakat sangat lemah atau kurang tentang hukum dan proses beracara pada persidangan di muka Pengadilan Agama.

2. Dengan menggunakan jasa advokat, maka akan mempermudah dan memperlancar jalannya persidangan, disebabkan karena mereka tahu dan paham tentang hukum dan proses beracara di muka persidangan.

\footnotetext{
${ }^{24}$ Jimly Assidieqy, op.cit, h. 199-200
} 
3. Orang yang menggunakan jasa advokat dalam menyelesaikan perkara di Pengadilan Agama, maka akan memperoleh hasil yang maksimal dibandingkan dengan menyelesaikan perkara sendiri tanpa bantuan jasa advokat.

Peran advokat yang berpraktek di Pengadilan Agama dalam memberikan jasa hukum dianggap positif bagi pencari keadilan, kebenaran dan penegakan hukum. Peran positif advokat itu dapat digambarkan dalam beberapa hal sebagai berikut:

1. Mempercepat penyelesaian administrasi perkara di Pengadilan Agama.

2. Membantu menghadirkan para pihak yang berperkara di Pengadilan Agama.

3. Memberikan pemahaman hukum yang berkaitan dengan duduk perkara dan posisinya terhadap para pihak dalam menyampaikan permohonan atau gugatan atau menerima putusan Pengadilan Agama.

4. Mendampingi para pihak yang berperkara di Pengadilan Agama sehingga mereka merasa terayomi keadilannya.

5. Mewakili para pihak yang tidak dapat hadir dalam proses persidangan, sehingga memperlancar proses persidangan.

6. Dalam memberikan bantuan hukum, sebagai advokat yang profesional, harus menjungjung tinggi sumpah advokat dan kode etik profesi dalam menjalankan peran sesuai dengan tugas dan fungsinya ${ }^{25}$.

Seorang advokat Indonesia harus memiliki kesediaan untuk memberikan nasehat dan bantuan hukum kepada setiap orang yang memerlukannya secara nondiskriminatif tanpa adanya perbedaan agama, kepercayaan, suku, bangsa dan lain sebagainya. Karena hal ini merupakan etika normatif yang menjadi kewajiban bagi advokat Indonesia, bahwa ia harus bersedia untuk memberi nasehat dan bantuan hukum kepada orang yang memerlukannya.

${ }^{25}$ Rahmat Rosyadi, op.cit, h. 70 


\section{Penutup}

1. Pemberian bantuan hukum kepada setiap orang sesungguhnya merupakan kewajiban moral bagi advokat tanpa adanya diskriminatif dengan tidak membedakan etnis, politis, dan strata ekonomi, baik di luar persidangan maupun dalam berperkara di lingkungan Pengadilan Agama. Secara yurudis ia juga didukung oleh ketentuan-ketentuan hukum dan nilai-nilai universal. Selain itu, secara sosiologis pemberian jasa hukum khusunya bagi masyarakat tidak mampu dalam upaya mencari kebenaran, menegakkan keadilan dan menjamin hak asasi manusia, maka seorang advokat dapat memberikan bantuan secara cuma-cuma kepada mereka atau dengan honorarium berdasarkan kesepakatan dan tingkat kewajaran serta kondisi kliennya.

2. Peran advokat di lingkungan Pengadilan Agama memberikan nilai yang positif dalam memberikan jasa hukum. Misalnya, mempercepat penyelesaian administrasi perkara, membantu melancarkan persidangan, membantu menghadirkan para pihak yang berperkara, memberikan pemahaman hukum berkaitan dengan pokok permasalahan yang dihadapi kliennya, mewakili para pihak yang tidak bisa hadir di persidangan, dan dalam memberikan bantuan hukum seorang advokat harus tetap menjungjung tinggi sumpah dan kode etik seorang advokat. 


\section{DAFTAR PUSTAKA}

Hadi Daeng Mapuna, Problematika Pelaksanaan Hukum Acara Peradilan Agama, Cet. I; Makassar: CV. Kencana, 2003

H.A Mukti Arto, Praktek Perkara Perdata pada Pengadilan Agama, Cet. I; Yogyakarta: Pustaka Pelajar, 1996

Ropaun Rambe, Teknik Praktek Advokat, Cet. I; Jakarta: PT. Grasindo Anggota IKAPI, 2001

Republik Indonesia, UU No. 18 tahun 2003 tentang advokat.

Sudikno Mertokusumo, Hukum Acara Perdata Indonesia, Cet. I; Yogyakarta: Liberty, 2002

Retno Sutianto dkk, Hukum Acara Perdata dalam Teori dan Praktek, Cet. II; Bandung: Mandar Maju, 1999

Lasdia Wlas, Cakrawala Advokat Indonesia, Cet. I; Yogyakarta: Liberty, 1989

Rahmat Rosyadi \& Sri Hartini, Advokat dalam Perspektif Islam dan Hukum Positif, Cet. I; Jakarta: Ghalia Indonesia Anggota IKAPI, 2003

Republik Indonesia, Kitab Undang-undang Hukum Pidana dan Kitab Undang-undang Hukum Acara Pidana, Cet. III; Jakarta: Gema Press, 2003

Jimly Assiddiqie, Hukum Acara Pengujian Undang-undang, Cet. I; Jakarta: Setjen dan Kepaniteraan MKRI, 2005

Republik Indonesia, Undang-undang No. 24 Tahun 2003 tentang Mahkamah Konstitusi disertai dengan Undang-undang No.18 Tahun 2003 tentang Advokat, Cet. I; Surabaya: CV. Karina Anfaka Perdana, 2003

Yudha Pandu, Klien dan Advokat dalam Praktek, Cet. III; Jakarta: PT. Abadi, 2004 Kehakiman.

Republik Indonesia, UU No. 14 Tahun 1970 tentang Kekuasaan 